\title{
The Economics Major is Not a Pipeline to Finance
}

\author{
David Colander \\ Middlebury College, Middlebury, Vermont 05753, USA
}

Eastern Economic Journal (2016) 42, 483-487. doi:10.1057/eej.2016.11

Economics is the largest major at Middlebury College where I teach, as it is at most top liberal arts schools. As an economics professor I am happy about this - it means we have a desirable major. Unfortunately, about 40 percent of our majors are majoring in economics not because they love economics, but because Middlebury, like most top liberal arts colleges, does not offer a business major. Students (and non-economics faculty) see the economics major as the best liberal arts preparation for a career in business which for many of my students means a job in finance. They are wrong; the economics major is not a pipeline into finance.

The reality is that an economics major does not prepare students for business or finance any better than do a dozen other liberal arts majors. ${ }^{1}$ A strong liberal arts training, almost regardless of major, combined with specific training in the practical skills and knowledge used in finance, is the actual pipeline to finance. The same holds true for just about any career.

\section{THE ECONOMICS MAJOR IS NOT DESIGNED TO PREPARE STUDENTS FOR FINANCE OR BUSINESS}

A primary reason the economics major is not a pipeline to finance or a business career is that it is not designed to be. Economics, like other liberal arts majors, is designed to provide students with general liberal arts skills. The economics major provides students with broad insights into how the economy works. It makes no attempt to teach students the specific skills and knowledge needed in business or finance. I am not saying that understanding economics is not useful in finance. Economics understanding is important for finance, but understanding economics is just as important for non-profits, government, or even the arts, as it is for finance.

Employers know that the economics major is not designed to train students in the specifics of business or finance. They hire liberal arts economics majors nonetheless because what they are most interested in is that their new hires have solid general liberal arts skills. (The same holds true for all employers: business, government and non-profits alike.) Employers' interest is in hiring students whom they believe can help them in their activities. They want employees who are self-starters, who can learn on their own, who can write, who can handle quantitative and qualitative reasoning, who are comfortable with critical thinking, who can deal with uncertainty, who can communicate verbally, and who 
play well with others in the sandbox (i.e. are comfortable working in teams). Those are all general liberal arts skills, which is why liberal arts colleges send so many students into finance. The entire liberal arts experience, not the economics major, prepares students for a career in finance or business.

The fact that financial firms hire liberal arts economics majors, even though the economics major doesn't teach them finance-specific skills, has an important implication. It means that there is no need to major in economics if a student wants to go into finance. Because enrollment pressures in economics lead to larger class sizes, other majors teach many general liberal arts skills as well or better than does an economic major. For example, a math major provides more training in quantitative reasoning; a philosophy major provides more training in qualitative reasoning, and a history or English major provides more training in writing and communicating. And just about any major provides better training in working in teams than do most economics majors. I could go on, but you get the picture. Finance firms are open to hiring a student with just about any major, as long as that student has strong liberal arts training combined with appropriate job-specific skills and knowledge.

\section{THE BENEFITS OF AN AVOCATIONAL MAJOR}

In fact, a strong argument can be made that another major might be better than an economics major to get a job in finance. The reason is that finance employers like multidimensional students who have a breadth of interests and knowledge. Majoring in a field unrelated to finance signals that the student has the courage and gumption to develop his or her other dimensions. Employers know that those other dimensions might be useful to them. Those employees in a finance company who majored in music, art, or literature often become the go-to person within the firm when something comes up (say an IPO of a music company) related to their interests.

All too often students choose their major thinking only about their likely future vocation, when they would be better off thinking about their major in terms of their likely future avocation. Choosing an "avocation major" rather than a "vocation major", shows you're a well-rounded person (and gives you something to talk about in an interview.)

\section{THE NEED FOR FINANCE-SPECIFIC TRAINING}

If your particular major does not matter that much to getting a job in finance, what does? The ideal path to a job in finance combines training in general liberal arts knowledge and skills with training in finance-specific knowledge and skills. So, besides being strong in general liberal arts skills, the ideal finance candidate will also have already learned the skills and practical contextual knowledge that are used in a finance career.

Liberal arts economics departments are not designed to teach those practical skills and knowledge, and it is almost never part of a liberal arts economics major. This makes some sense because such specific skills and knowledge are best learned on the job, and thus can only be understood and taught by someone who has been on the job. Academic finance professors who do not have practical experience in addition to their academic training are not the ones best suited to teach job-related skills and knowledge. Academic professors are best suited to teach students the skills needed to be a professor. So, for most students, the best path to a job in finance (or in any field) includes having worked in that field. That is why internships have become so important in getting a job in finance and elsewhere. 
Liberal arts schools around the country are struggling with the problem of how to provide students with job-specific skills and knowledge. To do it, they are increasing offerings of business type courses and creating minors with business-sounding names, such as managerial economics, entrepreneurial studies, or finance. But introducing such courses and creating such minors do not get at the real problem, which is that academics trained in graduate school are not the ones who are best suited to teach such courses at liberal arts schools. Unless these finance and business academics have practical experience in addition to their academic training, they don't have the contextual knowledge to convey. Moreover, specialist academic finance professors are too expensive for most liberal arts schools, since the business school salary structure is much higher than the liberal arts salary structure. ${ }^{2}$

\section{THE PROFESSOR OF THE PRACTICE (POP) PROGRAM}

To deal with these challenges, Middlebury has recently created a PoP program. ${ }^{3}$ The program grew out of the existing Executive in Residence program, but expanded it significantly and made it much more focused on teaching, and on bringing the executives into the classroom than was the case previously. The PoP program is built on the assumption that the best people to teach the skills needed in a career are the people who have been successful in that career. So the PoP program brings in successful people who are at a point in their career when they want to give back to society by teaching students how the liberal arts are used in the real world. It pairs these professors of the practice with academic liberal arts professor sponsors. These sponsors work with the professors of the practice on teaching the course. They do so by giving the PoP suggestions and guidance in teaching. The sponsor's role is to insure that the course both maintains academic rigor and asks broad liberal arts questions in addition to providing contextual knowledge of the field being taught. ${ }^{4}$

For example, in Middlebury's accounting and budgeting course, students go back to Luigi Pacioli's introduction of double entry bookkeeping and consider how its general adoption fundamentally changed society. They also consider how accounting might change for triple bottom line corporations. In finance, in addition to becoming facile with $d c f$ models in Excel, students consider the evolution of financial ideas over the last 50 years and how developments in the science of finance changed the practice of finance, not necessarily for the better.

All PoP courses have two goals. One is to provide students with an introduction to the specific skills and knowledge used in the real world; the second is to show them the broader liberal arts dimension of the course. By design, all PoP courses are interdisciplinary. Thus, finance is not presented as an economics subject, and journalism is not presented as a English subject. They are presented as applied liberal arts subjects that integrate a wide range of liberal arts skills. They are lab courses of the liberal arts.

Another way to think of the PoP program is as a reverse internship program. Rather than sending students to a real world internship to learn the skills - a process that is expensive and difficult to scale, the program brings in successful individuals who teach students the skills and knowledge that they would get in an ideal internship.

The success of the PoP program depends on finding the right individuals to teach the courses, and the right professors to sponsor the courses. The ideal PoP professor is wickedly smart, knowledgeable in teaching, highly successful in his or her field, and willing to work for avocational wages. (The pay is avocational, not vocational pay. PoP's are paid a small honorarium; the program makes no attempt to pay market wages.) Finding these individuals is 
not easy, but it can be done by tapping a school's alumni and friends network. The reality is that there are a large number of highly successful individuals who are willing to teach in the program as a way of giving back to society. At Middlebury, we have courses taught by a former neurosurgeon turned McKenzie management consultant, a former Insurance company $\mathrm{CEO}$, a former governor, a former judge, a former hedge fund manager, a former venture capitalist, and a former NPR producer. ${ }^{5}$ It takes time and effort to find these people, and to determine whether they fit the program, and it takes strong support from faculty sponsors to create an effective course. More, not less, thought has to go into choosing these people than goes into hiring a standard academic professor.

The PoP program goes far beyond finance; I focus on the PoP program here because it offers the best way for just about any liberal arts program to provide the appropriate training in finance. It is less theoretical and far more "practical skill and knowledge" oriented than an academic focused course. While it has vocational aspects, it is not vocational; in fact it is more liberal artsy than many standard academic courses, because the skills focused on tend to be interdisciplinary rather than field-specific skills. Courses focusing on real world areas are by nature applied liberal arts interdisciplinary courses. For example, in a PoP course, students do not do calculus-based problem sets; rather they do excel-based quantitative exercises that often do not have well-defined answers, and they do team-based projects and exercises that involve integrating qualitative and quantitative dimensions of problems into a written and verbal presentation, because that is what is done in the real world.

Currently, in finance, Middlebury offers an accounting and budgeting course, a finance course, a quantitative finance course and an investments course. ${ }^{6}$ This set of courses, combined with two or three relevant courses from computer science, statistics, and economics, provides students, regardless of major, with a superb liberal arts training for finance.

\section{ADVICE TO STUDENTS WHO WANT A CAREER IN FINANCE}

Let me conclude with my advice to my Middlebury students who want to get a job in finance: Major in whatever you want, but supplement that major with these financefocused PoP courses.

My advice to non-Middlebury students at other liberal arts colleges: Get your school to create a PoP program. Until they do, be creative about acquiring the finance-specific knowledge and skills you need. If possible, find an internship. If your school offers an accounting course and a finance course, take them, especially if they are taught by a professor with significant real world experience. If such courses are not available at your school, see if you can get credit for a course taken on those subjects over the summer or when studying abroad. Take them even if you do not get credit. Alternatively, take an online course in both accounting and finance. For background training in business, consider taking an introduction to business program such as the Harvard Business School's HBXCore course.

If you know people working in finance, spend time talking to them. Ask them to suggest books to read. Read those books; then discuss what you've read with others. Recognize that knowledge and skills do not need to come only from courses. Students taking the initiative in gaining the skills and information needed in a career will be seen positively by almost all employers.

\section{Notes}

1. Requirements for the economics major differ at different schools, and my focus here is on those liberal arts economic programs such as Middlebury's that do not offer, or, if they do offer them, do not require, and often do not give major credit for, "business" courses such as accounting or corporate finance. 
2. Try telling a liberal arts dean that you need to offer a new Ph.D. in finance a US\$180,000 salary to be competitive.

3. Middlebury's Professor of the Practice program is designed to provide practical training relevant to a wide variety of fields. Here I focus on finance, but the same reasoning carries over to many other fields; the professor of the practice program has courses involving podcasting, developing a literary magazine, management consulting, journalism, statesmanship, entrepreneurship, and technology.

4. Professors of the practice are extremely open to these issues. The reality is that practioners, especially ones who volunteer to work in the PoP program, recognize the broad liberal arts dimension of their field, often more so than do field-specific academics.

5. We find these people through word of mouth, and by working with Middlebury alumni, friends and parents network. Some had taught courses in winter term; others were parents or were involved with other Middlebury outreach programs.

6. The courses all include projects designed to teach students practical finance skills and knowledge. 